Check for updates

The BMJ

Cite this as: BMJ 2021;374:n2285

http://dx.doi.org/10.1136/bmi.n2285

Published: 16 September 2021

\section{Covid-19: Act now or hospital admissions could soar, experts tell government}

\author{
Gareth lacobucci
}

The NHS in England could see between 2000 and 7000 admissions of people with covid to hospital next month if ministers are too slow to reintroduce precautionary measures, government scientific advisers have warned.

On 14 September the government published its covid-19 response plan for autumn and winter, which pledged to reintroduce a range of precautionary measures-including a legal requirement to wear face coverings, advising people to work from home if they are able to, and mandatory vaccine certification-if a further surge in cases threatens to overwhelm the NHS. ${ }^{12}$

But new modelling from the government's Scientific Pandemic Influenza Group on Modelling (SPI-M-O), a subgroup of the Scientific Advisory Group for Emergencies (SAGE), notes that cases, hospital admissions, and deaths from covid are all higher than a year ago despite the success of the vaccination programme. ${ }^{3}$

"A basket of measures, light enough to keep the epidemic flat, would be sufficient if enacted when hospitalisations were at a manageable level," the group said. "If the epidemic were allowed to continue to grow until hospitalisations were at a level that needed to be rapidly reduced, much more stringent (and therefore more disruptive) measures would be needed to bring prevalence down quickly."

The UK is currently seeing around 1000 covid hospital admissions a day and has more than 8000 patients in hospital with covid. ${ }^{4}$ This compares with around 200 admissions a day and 1000 patients in hospital a year ago. On 5 November 2020, when the second national lockdown came into force in England, the UK had 1500 admissions a day and 14000 people in hospital with covid.

SPI-M-O said there was a "clear consensus" that the high number of people continuing to work from home had helped prevent sustained growth in cases in recent months, and it warned that removing this lever was likely to result in "a rapid increase in hospital admissions."

"If enacted early enough, a relatively light set of measures could be likely be sufficient to curb sustained but slow growth [in admissions]," the group said. "As well as encouraging home working, more light touch measures could include clear messaging that recommends people acting cautiously, more widespread testing, a return to requiring all contacts of cases to isolate, and more mask wearing."

This message was reinforced by SAGE in minutes published on 14 September. 5 "Early, 'low-cost' interventions may reduce need for more disruptive measures and avoid an unacceptable level of hospitalisations," it said. "Late action is likely to require harder measures."

Chaand Nagpaul, BMA council chair, urged ministers to "open their eyes and realise that now is the time to act."

He warned, "If left too late, we could find ourselves in a position where the NHS is dangerously overwhelmed, returning to a situation where ambulances were queueing round corners and hospitals had no choice but to pause all elective care, further increasing the already enormous backlog."

\section{"Winter is already here"}

Dale Gardiner, an intensive care doctor in the English Midlands and a board member of the Faculty of Intensive Care Medicine, told The BMJ about the pressure he and other NHS doctors were currently facing with the level of covid on the wards. "People are worried about the winter, but, honestly, winter is already here for the NHS," he said.

"We've got the highest number of covid patients in intensive care since March, and that's across the UK. In the Midlands, around $40 \%$ of intensive care beds are currently occupied by covid patients. That's $40 \%$ of beds where we can't provide care for other patients-for example, those needing cancer and time sensitive surgery.”

Gardiner added, "I think the situation in the NHS is in a worse state now than at the height of the pandemic. The covid numbers might have been higher in the past, but at the time hospitals were doing very little of the other vital work we normally do. Now we're trying to do both-there is a massive backlog."

Government HM. Covid-19 response: autumn and winter plan. Sep 2021 https://assets.publishing.service.gov.uk/government/uploads/system/uploads/attachment_data/file/1017404/COVID-19-response-autumn-andwinter-plan-2021.pdf.

2 lacobucci G. Covid-19: Government lays out its "plan B" to protect NHS this winter. BMJ 2021;374

3 Scientific Pandemic Influenza Group on Modelling. Operational sub-group (SPI-M-O), for the Scientific Advisory Group for Emergencies (SAGE). Consensus statement on covid-19. Sep 2021. https://assets.publishing.service.gov.uk/government/uploads/system/uploads/attachment_data/file/1017129/S1376_SPI-M-O_Consensus_Statement.pdf.

4 Gov UK. Healthcare in United Kingdom: patients admitted to hospital. https://coronavirus.data.gov.uk/details/healthcare.

5 Ninety-fifth SAGE meeting on COVID-19, 09 September 2021 Held via Video Teleconference. https://assets.publishing.service.gov.uk/government/uploads/system/uploads/attachment_data/file/1017296/S1360_SAGE_95_minutes.pdf.

This article is made freely available for use in accordance with BMJ's website terms and conditions for the duration of the covid-19 pandemic or until otherwise determined by BMJ. You may use, download and print the article for any lawful, non-commercial purpose (including text and data mining) provided that all copyright notices and trade marks are retained. 